\title{
Nutrition planning: the poverty of holism
}

Donald S. McLaren, of the Department of Physiology at Edinburgh University's Medical School, criticises the approach of the planners to the problems of world nutrition

SINCE the World Food Conference in Rome in 1974 there has been a rising tide of proposals for nutrition planning, policies and strategies on both national and international scales. The United Nations, for example, has given its blessing through the FAO/WHO report on 'Food and Nutrition Strategies in National Development', and has further encouraged the trend through the choice of 'The importance of national and international food and nutrition policies for health development' as the topic for technical discussion at the recent World Health Assembly. But the proposals are shibboleths of holism that, lamentably, have gone unchallenged.

The holistic approach has undoubtedly had its triumphs, where the problem was appropriate and the means available made it amenable. The Manhattan Project and the American and Russian space programmes are obvious examples. But the disappointing results in medicine of the American Heart, Stroke and Cancer programme and of Britain's National Health Service, and the failure of numerous attempts to control population increase, suggest that in certain areas of social action guerilla tactics and not a war machine are required, giving flexibility, accountability and proven effectiveness. Nutrition is just such an area.

The new breed of nutrition planners have a disturbing predilection for coining vague neotechnologisms and drawing maze-like flow (or are they ebb?) diagrams. That is bad enough. But they also choose to ignore those harsh realities that do not fit into their preconceived schemes. Ironically, a prime example is the phenomenon as ugly as its own 'neotechnological' name: Agripower. The probing of the United Nations Research Institute for Social Development and others, for example, recently highlighted by Susan George in How the Other Half Dies: the Real Reasons for World Hunger, show how the world's poor and hungry are increasingly at the mercy of vast agri-business corporations (chiefly from the United States), of Western governments with their food 'aid' policies, and of supposedly neutral multilateral development organisations, like the World Bank-all of them, so the argument runs, working in collusion with local elites nurtured and protected by the powerful in the developed world.

Then there is the case of Scientific American devoting an entire issue to food and agriculture. The problems of food and nutrition were there dismissed as being entirely technological in nature and capable of solution by "additional technology and capital from the developed countries"-a root cause rather than a solution. Ironically, the numerous lavish advertisements documented the frightening story of US agripower that was shunned in the text. Rarely do the institutions responsible permit themselves to make statements on the ethical implications of their activities. It probably takes someone like the former US Secretary of Agriculture, Earl Butz, to admit that "Food is a weapon. It is now one of the principle tools in our negotiating kit"and we know what happened to him.

What has been ignored throughout such deliberations is the different nature of the two problems of food supply and human nutrition. It was this misconception which contributed to the failure of the UN Freedom from Hunger Campaign in the mid-1960s and to the Great Protein Fiasco of the early 1970s, as I pointed out in The Lancet at these times. Food shortage is a necessary but not adequate cause of undernutrition. There is many a slip betwixt the cup of food supply and the lip of hungy man. Problems with the former are necessary, but not adequate, causes of those of the latter. That is why the Green Revolution has not resulted in less malnutrition.

Nutrition planners state that past efforts failed, if failed they did, because they were piecemeal and for no other reason; they claim that a new planned approach must succeed because it is holistic and not piecemeal. Now the term 'whole' has two senses, as Popper indicated in The Poverty of Historicism: the totality of all the properties or aspects of a thing; and the special properties of certain things which make them appear to be an organised structure rather than a 'mere heap'. Popper's argument is clear: though wholes in the latter sense have often been made the object of scientific study (notably by the 'Gestalt' school of psychology), in a social context the 'organised structure' in no way applies and holism is inappropriate. Methodological problems have not been surmounted and there is no reliable procedure for building hypotheses based on well devised observations, experiments or rational deductions. Holistic or Utopian social engineering is always public and not private, aims at remodelling the whole of society and extending the power of the state, and smacks of tyranny. The alternative is piecemeal social engineering, the word piecemeal having no pejorative sense but meaning just what it says-piece by piece or part at a time.

Past achievements of the piecemeal approach to nutritional problems, it is true, are not impressive. Iodisation of table salt is effective against simple goitre. Fortification of staple foodstuffs has helped to maintain optimum micronutrient status in many populations. Prevention of the most common deficiency, iron, remains unachieved everywhere. Classical vitamin deficiencies have been influenced most by political action and social change-the disappearance of beriberi and xerophthalmia from Japan in the early part of this century, of pellagra from the southern United States initiated by the immigration laws in the 1920s, and the emergence of rickets in British Asian immigrants. The widespread intractable problem of the malnutrition-infection complex of early childhood in developing countries has deep socio-economic roots. Mothercraft and nutritional rehabilitation centres have made modest but real contributions.

In those communities where overnutrition and nutritionrelated degenerative diseases are rife, it remains to be seen whether the health of the increasingly diet-conscious public will benefit from the multifarious and often conflicting advice it is being offered. In the meantime the fact is that nutrition remains largely one of Medawar's 'kitchen arts'a science insufficiently underpinned by theory. A halt should be called to the present mania for holistic day dreaming. Research efforts should be renewed to bring order to the present 'mere heap' so that sounder measures may result, piecemeal though they may be. The WHO's resolution at its recent assembly, urging the eradication of the severe clinical forms of malnutrition by the turn of the century, offers at least some hope.

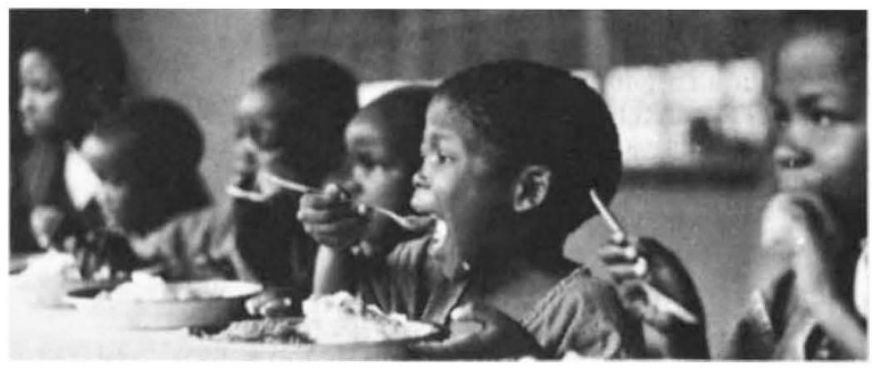

Hospital meals; effective against malnutrition? 